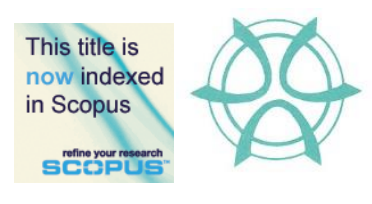

PLANNING MALAYSIA:

Journal of the Malaysian Institute of Planners

Volume XI (2013), Page 59 - 84

\title{
SUSTAINABLE FOREST MANAGEMENT IN LOWER KINABATANGAN, SABAH: ISSUES AND CURRENT PRACTICES
}

\author{
Normah Abdul Latip ${ }^{1}$, Nurwati Badarulzaman ${ }^{2}$, Azizan Marzuki ${ }^{3}$ \& Mohd \\ Umzarulazijo Umar ${ }^{4}$ \\ ${ }^{1,2,3 \& 4}$ School of Housing, Building and Planning \\ UNIVERSITI SAINS MALAYSIA
}

\begin{abstract}
Since 1992, when the first United Nations' Earth Summit was held in Rio de Janeiro, sustainable forest management (SFM) has been increasingly used to maintain a balance between social, economic and environmental development. In line with this, the successful implementation of SFM depends in large measure on the involvement of all the stakeholders. However, in the Lower Kinabatangan area, not all the stakeholders, especially the local community, are involved in the decision making process when it comes to forest management. The primary objective of this research is to explore the views of the three major stakeholders (Government, Private Sector and Local Community) with regard to issues concerning the environment, the current methods of forest management and the factors that are having an impact on SFM in Lower Kinabatangan. The quantitative method was used in this research and the data was obtained through questionnaires which were distributed to a stratified sample of the target population of stakeholders. Of the 160 questionnaires that were distributed, 115 or $56 \%$ of them were returned. The data analysis revealed some similarities and differences in the viewpoints of the stakeholders. It was found from this research that the majority of the respondents were in favour of improving forest management as a way to solve the environmental issues that have arisen in Lower Kinabatangan.
\end{abstract}

Keywords: sustainable forest management, environmental conservation, sustainable agriculture

${ }^{1}$ Normah Abdul Latip is a lecturer at the School of Housing, Building and Planning, Universiti Sains Malaysia, Pulau Pinang, Malaysia. Email: norma_abdlatip@yahoo.com 
Normah Abdul Latip , Nurwati Badarulzaman, Azizan Marzuki \& Mohd Umzarulazijo Umar

Sustainable Forest Management in Lower Kinabatangan, Sabah: Issues and Current Practices

\section{INTRODUCTION}

The forest is rich in natural resources and many people living in the rural areas in developing countries depend heavily on these resources for their economic and social development (Kohm \& Franklin, 1997). An estimated 60 million natives rely on the forests. This means that 350 million people subsist on and derive their earnings from forest resources, while 1.2 billion people are involved in agroforestry farming (World Bank, 2006). For this reason, it is acknowledged that forests can be the answer to the eradication of poverty. However, the FAO (2001) reported that forests in the tropical regions of the world have been decreasing at an alarming rate of 9.2 million hectares $(0.52 \%)$ annually from 1990 to 2000. This on-going decline of tropical forests worldwide has become an important topic of discussion among both developed and developing countries. As such, it is the general consensus that if the brakes are to be put on the current destruction of tropical forests, then it is essential that the concept of sustainable forest management (SFM) be sanctioned (Cissel et al., 1994). In line with the policy debates that have been held globally, such as the Rio Declaration and Forest Principles in 1992, many countries have gradually changed their definition of SFM from one that concentrates on maintaining timber production to one that includes the economic, environmental and social dimensions of forest management (Cissel et al., 1994). Beside, according to Halimaton Saadiah et al (2011), SFM can be achieving by integrated land use planning, conservation and development through the Geopark concept. Geopark concept, developed by the Global Geopark Network (GGN), and endorsed by the United Nations Economic and Cultural Organisation (UNESCO), is a concept which conserves natural and cultural heritage while enhancing socioeconomic development for the sustainable wellbeing of the local population. Conservation through tourism also becomes important element for achieving the SFM. According to Ong Puay Liu and Sharina (2011), tourism is a commercial enterprise, it has an important role in ensuring the natural environment wellprotected, and local communities' cultural traditions safeguarded.

This research presents the results of an analysis that was carried out on the incentives for achieving sustainable forest management and an assessment of several challenges and contentious issues concerning the main stages of sustainable forest management in a case study of Lower Kinabatangan, Sabah, Malaysia. 


\section{PROBLEM STATEMENT}

Sabah has the largest acreage of oil palm plantations in Malaysia and has been a major contributor to the economic development of the country (Hoh \& Ishak, 2001). The total area under oil palm in Sabah has risen to 1.4 million hectares and 5.3 million tons of crude palm oil came from this state in 2010. The palm oil industry is a major sector in the state's economy and it plays an influential role in the international edible oils market. At present, palm oil is the largest contributor to the economy of Sabah. In view of this, the growing concern among policy makers and the public that the biofuel policies in Malaysia may eventually lead to the rainforests in Sabah being replaced by oil palm plantations is logical. Such a result would damage the promotion of the environmental benefits of biofuels and destroy the ecology, with subsequent impacts on the economy and society. Over the past few years the focus has mainly been on the effects of replacing the forests with oil palm, but little is known about the increasing depletion of forests due to biofuel production (Hoh \& Ishak, 2001).

In a recent report authorized by the government of the United Kingdom, it was revealed that the shift in demand from agricultural produce to biofuels is causing rapid changes in the usage of land, and if this persists the biodiversity will be reduced and it may even result in increased GHG emissions instead of a reduction (Gallagher and Patrick-Riley, 1989). From 1990 to 2005, more than $50 \%$ of the expansion of oil palm plantations in Sabah occurred through the clearance of forests (Koh \& Wilcove, 2007). However, several changes were implemented in 1997. It was apparent from the on-going destruction of the forests in Sabah that the amendments to the Forest Enactment in 1984 had failed to preserve the forests and to provide better forest management. The state government changed its policy and instead of short-term licences, long-term licences were issued, such as the Sustainable Forest Management License Agreement (SFMLA), so as to foster more efficient forest management (Sabah Forestry Department, 1998). The aim is to preserve what remains of the forests and to maintain them in a sustainable manner so as to efficiently manage the production of timber for the long term and to protect the environment. The conditions imposed for the issuance of the licences are based on a model forest project in the Deramakot Forest Reserve, which is run by the SFD within the FMU. The Forest Stewardship Council (FSC) has certified that this project has met its principles and criteria for a well-managed project (Sabah Forestry Department, 2007a). Mannan and Yahya (1997) have identified several factors that have caused the widespread destruction of forests in Sabah, such as harvesting faster than the forest is able to regenerate; premature "entry" or "relogging" which do not give forests a chance to recover after logging activities; 
Normah Abdul Latip , Nurwati Badarulzaman, Azizan Marzuki \& Mohd Umzarulazijo Umar

Sustainable Forest Management in Lower Kinabatangan, Sabah: Issues and Current Practices

bad logging methods that cause damage to residual stands; neglect of silviculture and forest rehabilitation; monetary gain prevailing over environmental restrictions; political changes and instability, and the inability of forestry experts to put pressure on powerful groups. From 1975 to 1995, the area of primary forest cover shrank from an estimated 2.8 million hectares to approximately 300,000 hectares (Mannan \& Yahya, 1997) and during that same period, the area of disturbed forests almost doubled. Mannan and Yahya (1997) observed that the most drastic change occurred in the primary forests under the Class II Production Forest category, where the cover was reduced from $98 \%$ in 1970 to a mere $15 \%$ in 1996. At the same time, the first major change in forest laws took place when the Forest Enactment of 1968 was revised in 1984. This revision resulted in the division of forest reserves into seven classes, the regazetting of all existing forest reserves to include these new classes, and the gazetting of new reserves. For example, the Deramakot Forest Reserve has been classified as the Deramakot Forest Reserve, and this change indicated that forest reserves, especially those in the Class II Commercial Forest category, could no longer be reclassified within the Sabah Forest Department but that the reclassification had to be approved by the State Cabinet and the Governor of Sabah (Sabah Forestry Department, 2007a). According to Payne (1997), the advancing disappearance and destruction of tropical rainforests in Lower Kinabatangan, Sabah, Malaysia is a major threat to the environment. Lower Kinabatangan, which is the largest and most important wetland in Sabah, Malaysia, is made up of various types of forests such as freshwater swamp forests, secondary dry land forest, limestone outcrops and lakes (WWF Malaysia, 2004). A century ago the Lower Kinabatangan was practically covered by forests but today these forests have had to make way for agriculture and the few remaining forests have been badly damaged (WWF Malaysia, 2005). On the whole, these problems have brought to the surface the weaknesses that existed in the previous concepts, planning and implementation of forest management in Sabah, such as inadequate cooperation and coordination among the various government extension agencies; lack of prioritization, commitment and support for forest management projects from stakeholders; absence of community participation, meaning that the various communities were left out of the planning and decision making process for forest management, and were not given enough information regarding the aims and objectives of forest management; poor communication due to cultural differences between extension personnel and communities; disunity and internal problems within resettled villages, for example, land and border conflicts and complete reliance on financial aid from the government (Mannan \& Yahya, 1997). In addition, some environmentalists claim that unless serious measures are taken to implement sustainable forest management, $98 \%$ of the rainforests in Indonesia and Malaysia will have disappeared in 15 years' time. 


\section{RESEARCH OBJECTIVES}

This research investigates the management of forests particularly with regard to the conversion of forests for agricultural use, the current forest management system and the sustainable forest management process in Lower Kinabatangan based on the views of the three major stakeholders (Government, Private Sector and Local Community).

The objectives of this research are as follows:

i. To explore the views of the three major stakeholders (Government, Private Sector and Local Community) concerning the environmental issues affecting the Lower Kinabatangan area.

ii. To examine the views of the three major stakeholders (Government, Private Sector and Local Community) concerning the current forest management practices in the Lower Kinabatangan area.

\section{METHODOLOGY}

The data for this research was collected through quantitative methods during a field survey in Lower Kinabatangan, Sabah. The primary data was obtained through the distribution of questionnaires and interviews of stakeholders, while the secondary data was obtained from the appropriate documents concerning the case study such as reports, plans and brochures. During trips to the case study area, observations were made at several important meetings, gatherings and workshops and notes were taken to be used as additional or secondary data. Various types of data were obtained from previous researches, government departments, universities and NGO offices such as maps (showing Kinabatangan, Sabah; the forest distribution in Malaysia; the land use in Lower Kinabatangan; and changes in forest cover in the world) and statistical data (on types of forests in Sabah and Lower Kinabatangan; on changes in forest cover in Sabah, Malaysia; and on fragmented land in Lower Kinabatangan due to the development of oil palm plantations). The data was obtained mainly from newspapers, dissertations, annual reports, journal articles, policies, legal documents and statistics. Data was also gathered from the Sabah Forestry Department (SFD), Sabah Wildlife Department (SWD), Kinabatangan District Office, HUTAN-French WWF, PACOS TRUST, Partners for Wetlands (Malaysia WWF), Sabah Town and Regional Planning Department, Sabah State Library HQ and branches, Environmental Conservation Department, University of Malaysia Sabah, and the Sabah Branch of the WWF. 
Normah Abdul Latip , Nurwati Badarulzaman, Azizan Marzuki \& Mohd Umzarulazijo Umar

Sustainable Forest Management in Lower Kinabatangan, Sabah: Issues and Current Practices

This research made use of the Probability Sampling method, specifically the Stratified Random Sampling method, due to the homogeneity of the population. Furthermore, in this method each member of the population (subdivision) has an equal chance of being selected and thus the final result is truly representative of the whole population. Stratified random sampling is a sampling method in which a population is divided into $\boldsymbol{L}$ (strata) mutually exclusive and exhaustive strata, and a simple random sample of $\boldsymbol{n}$ elements is taken within each stratum $\boldsymbol{n}_{\mathrm{h}}$. The sampling is then performed independently within each stratum (Yamane, 1967). According to Yamane (1967), a stratified random sample is obtained the same way as a simple random sample, but the sampling is done separately and independently within each stratum. If $N_{1}$, $N_{2}, \ldots, N_{L}$ represent the number of sampling units within each stratum, and $\boldsymbol{n}_{1}, \boldsymbol{n}_{2}, \ldots, \boldsymbol{n}_{L}$ represent the number of randomly selected elements within each stratum, then the total number of possible stratified random samples is $\left(N_{1} / \boldsymbol{n}_{1}\right) \mathbf{x}$ $\left.\left(\boldsymbol{N}_{2} / \boldsymbol{n}_{2}\right) \times \ldots \times N_{L} / \boldsymbol{n}_{L}\right)$ which is less than or equal to $(\boldsymbol{N} / \boldsymbol{n})$, the number of possible samples based on simple random sampling (Yamane, 1967). Yamane (1967) also stated that stratified random sampling has many advantages. It is as uncomplicated as simple random sampling and yet, in many cases, it is more reliable. It is also a convenient method for obtaining individual approximations for parameters for each subdivision in which the size of the sample is fixed and is not some arbitrary variable. Finally, this method ensures that the sample is typical of the population. The sample size was determined as follows according to the stratified random sampling method (Yamane 1967):

First, the population was divided into a set of smaller non-overlapping sub-groups (strata), and then a simple random sampling was performed independently in each sub-group (stratum). Normally, the size of the sample in each stratum is proportionate to the size of the stratum. This is known proportional allocation. There were three sub-groups or strata for this study.

\section{Strata}

Strata 1 (Government Group)

Strata 2 (Private Sector Group)

Strata 3 (Local Community Group)

Total

\section{Population (Size)}

$N_{1} 105$

$N_{2} 80$

$N_{3} 98$

For this study, 160 samples were obtained and divided into the above strata categories. The first step involved finding the total number of samples, $\boldsymbol{N}$ (283), and calculating the percentage in each group.

- $\% \mathrm{~N} 1=105 / 283=37 \%$

- $\% \mathrm{~N} 2=80 / 283=28 \%$

- $\% \mathrm{~N} 3=98 / 283=35 \%$ 
Thus, out of 160 samples,

- $\quad 37 \%$ should be $N_{1}$.

- $37 \%$ of 160 is 59 .

- $\quad 28 \%$ should be $N_{2}$.

- $35 \%$ should be $N_{3}$.

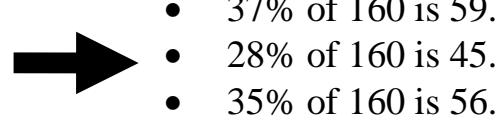

Another simple way to do this without calculating the percentage is to multiply each group size with the sample size and divide that by the total population size (size of whole population or group):

- $n_{1}=105 \times 160 / 283$, so $n_{1}=59$

- $n_{2}=80 \times 160 / 283$, so $n_{2}=45$

- $n_{3}=98 \times 160 / 283$, so $n_{3}=56$

The sample size was determined as follows by using the stratified random sampling approach (Yamane 1967):

$n=N /[1+N(e 2)]$

where $n=$ sample size, $N=$ population size, $\mathrm{e}=$ error of estimation; the confidence level is at $95 \%$ and the error margin is at $5 \%$. The sample size was calculated as:

$$
n=\frac{283}{(283 \times 0.05)^{2}+1}=160
$$

\begin{tabular}{|l|l|l|}
\hline Strata & Population $(N)$ & Sample size $(n)$ \\
\hline Strata 1 (Government Group) & $N_{1} 105$ & $n_{1}=59$ \\
\hline Strata 2 (Private Sector Group) & $N_{2} 80$ & $n_{2}=45$ \\
\hline Strata 3 (Local Community Group) & $N_{3} 98$ & $n_{3}=56$ \\
\hline Total & 283 & 160 \\
\hline
\end{tabular}

In this study, 283 questionnaires were distributed to the three different groups of respondents via email and "face to face" interviews. Of that number, 160 questionnaires $(56 \%)$ were returned, of which 45 were rejected and only $115(\mathrm{GG}=48, \mathrm{PSG}=35$ and $\mathrm{LCG}=32$ ) could be used. Therefore, on the whole, the sample size for the current study was only $40.6 \%$ or 115 respondents out of a population of 283 . Generally, a researcher will not do a factor analysis on a sample size of less than 50 and ideally a sample size of 100 or more is required (Bartlett, Kotrlik, and Higgins (2001). In quantitative data analysis methods, software packages such as Microsoft Excel and SPSS 12.0 are used to prepare graphs and for statistical analysis of the data. Different statistical and economic analyses were applied to the quantitative data in order to achieve the objectives of this study. First, simple descriptive statistics (such as the mean, standard deviation, etc.,) were calculated to determine the main characteristics of 
Normah Abdul Latip , Nurwati Badarulzaman, Azizan Marzuki \& Mohd Umzarulazijo Umar

Sustainable Forest Management in Lower Kinabatangan, Sabah: Issues and Current Practices

respondents and the values of some parameters of interest in relation to the SFM practices in the area under study. The data from the questionnaires were keyed into a Microsoft Excel file and the SPSS software program, which is normally used for social science studies, was used to perform a statistical analysis of the data. Descriptive statistics such as simple mean responses and F-tests were employed for the analysis. An analysis of Variance (ANOVA) test was used to generally examine the perceptions, understandings and beliefs of the various groups of respondents with regard to sustainable forest management practices in the study area. When the significance level $p \leq 0.05$, the results are said to be significant.

\section{RESULTS AND DISCUSSION}

The answer to the first and second objectives of this research will come from the results of the questionnaire. The details in this section were based on a field survey of 115 respondents in the Lower Kinabatangan. The respondents were divided into three categories, the Government $(G)(n=48)$, the Private Sector (PS) $(n=35)$ and the Local Community Group (LC) $(n=32)$. These sections were concerned with the viewpoints of the main stakeholders (G, PS and LC) with regard to the impact of environmental issues on the Lower Kinabatangan and also the current forest management practices in the Lower Kinabatangan area.

\section{Perceptions and Attitudes of Respondents towards Environmental Issues}

This section is concerning the first objective of this research regarding the perception of the three main stakeholders towards the environmental issues in the research area. In terms of environmental issues, the results indicate that the main concerns of all the respondents from the Government, Private Sector and Local Community are floods $(10.24 \%, 7.68 \%$ and $17.07 \%)$ and water pollution $(16.56 \%, 13.70 \%$ and $4.36 \%)$, while wildlife conservation is their fourth concern in the Lower Kinabatangan (Figure 1). On the whole, all the respondents shared similar views on these issues. 


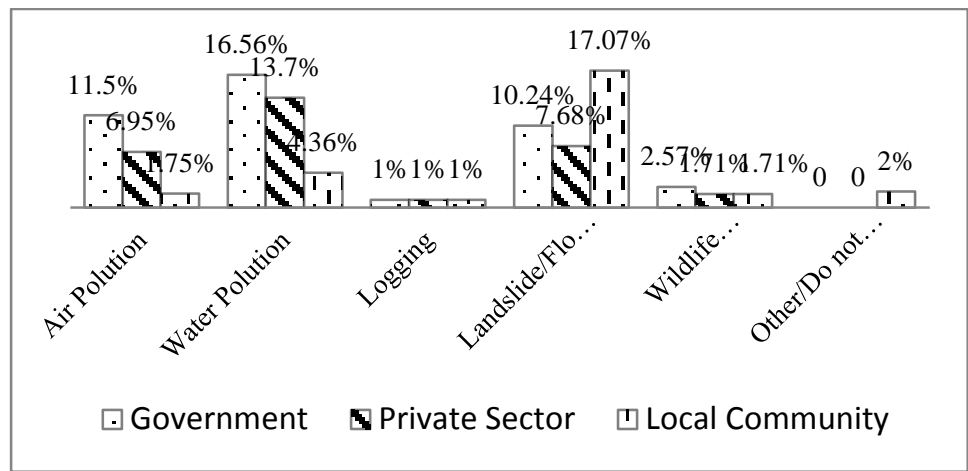

Figure 1: Ranking of environmental problems in Lower Kinabatangan $(n=115)$

In this section, to determine the awareness of the people with regard to environmental issues, the attitudes or perceptions of the respondents towards the protection of sustainable forest resources were examined further. A list of attitudinal statements concerning sustainable forest resources and their protection was given to the respondents and they were then asked to indicate whether they agreed or disagreed with each statement. The overall result showed that the respondents responded very positively towards the conservation of natural resources (Table 1).

Table 1: Attitudinal Statements on protection of forest resources and the percentage of respondents who agreed and disagreed with each statement (n-115)

\begin{tabular}{|c|c|c|c|c|c|c|}
\hline & & $\begin{array}{l}\text { Strongly } \\
\text { Agree } \\
(\%)\end{array}$ & $\begin{array}{l}\text { Agree } \\
(\%)\end{array}$ & $\begin{array}{l}\text { No } \\
\text { Opinion } \\
(\%)\end{array}$ & $\begin{array}{l}\text { Disagree } \\
(\%)\end{array}$ & $\begin{array}{l}\text { Strongly } \\
\text { Disagree } \\
(\%)\end{array}$ \\
\hline \multirow{3}{*}{$\begin{array}{l}\text { It is our } \\
\text { responsibility } \\
\text { to protect the } \\
\text { environment } \\
\text { from } \\
\text { development } \\
\text { (regardless of } \\
\text { the cost) }\end{array}$} & $\begin{array}{l}\text { Governm } \\
\text { ent }\end{array}$ & 11.14 & 21.72 & 1.76 & 4.54 & 2.4 \\
\hline & $\begin{array}{l}\text { Private } \\
\text { Sector }\end{array}$ & 0.0 & 22.59 & 1.76 & 4.54 & 1.6 \\
\hline & $\begin{array}{l}\text { Local } \\
\text { Communi } \\
\text { ty }\end{array}$ & 6.57 & 8.69 & 11.47 & 1.0 & 0.0 \\
\hline \multirow{3}{*}{$\begin{array}{l}\text { We should } \\
\text { reduce our use } \\
\text { of the } \\
\text { environment } \\
\text { now so that the } \\
\text { next generation } \\
\text { may benefit } \\
\text { from it. }\end{array}$} & $\begin{array}{l}\text { Governm } \\
\text { ent }\end{array}$ & 24.26 & 17.37 & 0.0 & 0.0 & 0.0 \\
\hline & $\begin{array}{l}\text { Private } \\
\text { Sector }\end{array}$ & 3.46 & 21.72 & 2.5 & 2.0 & 1.0 \\
\hline & $\begin{array}{l}\text { Local } \\
\text { Communi } \\
\text { ty }\end{array}$ & 11.26 & 13.90 & 2.5 & 0.0 & 0.0 \\
\hline \multirow{2}{*}{$\begin{array}{l}\text { Malaysia needs } \\
\text { to develop the } \\
\text { forests, seas, } \\
\text { and land to }\end{array}$} & $\begin{array}{l}\text { Governm } \\
\text { ent }\end{array}$ & 7.94 & 13.28 & 0.0 & 18.0 & 2.53 \\
\hline & $\begin{array}{l}\text { Private } \\
\text { Sector }\end{array}$ & 5.29 & 15.05 & 1.0 & 6.58 & 1.69 \\
\hline
\end{tabular}


Normah Abdul Latip , Nurwati Badarulzaman, Azizan Marzuki \& Mohd Umzarulazijo Umar Sustainable Forest Management in Lower Kinabatangan, Sabah: Issues and Current Practices

\begin{tabular}{|c|c|c|c|c|c|c|}
\hline $\begin{array}{l}\text { create jobs and } \\
\text { incomes } \\
\text { (regardless of } \\
\text { the } \\
\text { environmental } \\
\text { damage) }\end{array}$ & $\begin{array}{l}\text { Local } \\
\text { Communi } \\
\text { ty }\end{array}$ & 1.76 & 1.77 & 0.0 & 17.14 & 6.76 \\
\hline \multirow{3}{*}{$\begin{array}{l}\text { Even though I } \\
\text { don't use the } \\
\text { forest } \\
\text { resources now, } \\
\text { I am prepared } \\
\text { to pay to } \\
\text { protect them in } \\
\text { case I want to } \\
\text { use them in the } \\
\text { future }\end{array}$} & $\begin{array}{l}\text { Governm } \\
\text { ent }\end{array}$ & 0.0 & 19.03 & 0.0 & 22.38 & 0.0 \\
\hline & $\begin{array}{l}\text { Private } \\
\text { Sector }\end{array}$ & 2.0 & 17.30 & 0.0 & 11.18 & 0.0 \\
\hline & $\begin{array}{l}\text { Local } \\
\text { Communi } \\
\text { ty }\end{array}$ & 0.0 & 8.65 & 7.82 & 9.46 & 2.0 \\
\hline \multirow{3}{*}{$\begin{array}{l}\text { It is worth } \\
\text { spending } \\
\text { money to } \\
\text { protect the } \\
\text { forests because } \\
\text { they help to } \\
\text { protect the } \\
\text { sustainable } \\
\text { ecosystem in } \\
\text { the area }\end{array}$} & $\begin{array}{l}\text { Governm } \\
\text { ent }\end{array}$ & 2.64 & 39.29 & 0.0 & 0.0 & 0.0 \\
\hline & $\begin{array}{l}\text { Private } \\
\text { Sector }\end{array}$ & 3.53 & 13.29 & 5.0 & 5.83 & 3.0 \\
\hline & $\begin{array}{l}\text { Local } \\
\text { Communi } \\
\text { ty }\end{array}$ & 8.82 & 9.61 & 5.0 & 4.16 & 0.0 \\
\hline
\end{tabular}

\section{Respondents' Perception on Willingness to pay (WTP) for Sustainable Forest Management}

On the whole, 58 respondents $(50.43 \%)$ indicated a positive willingness to pay (WTP) for the conservation of the forest resources in Lower Kinabatangan, while 57 of them $(49.57 \%)$ responded negatively and refused to answer the WTP question (see Figure 2(a) and Figure 2(b).

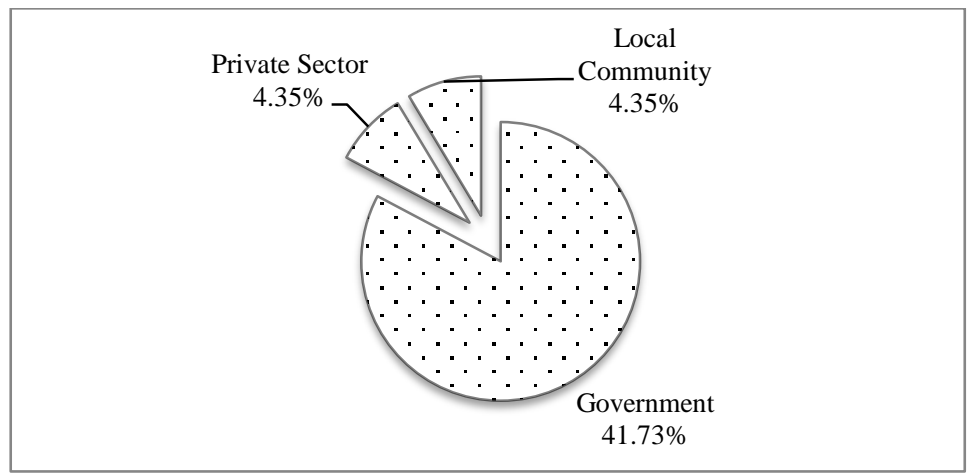

Figure 2(a). Summary of "Yes" responses to the willingness to pay question ( $\mathrm{n}=58)$ 


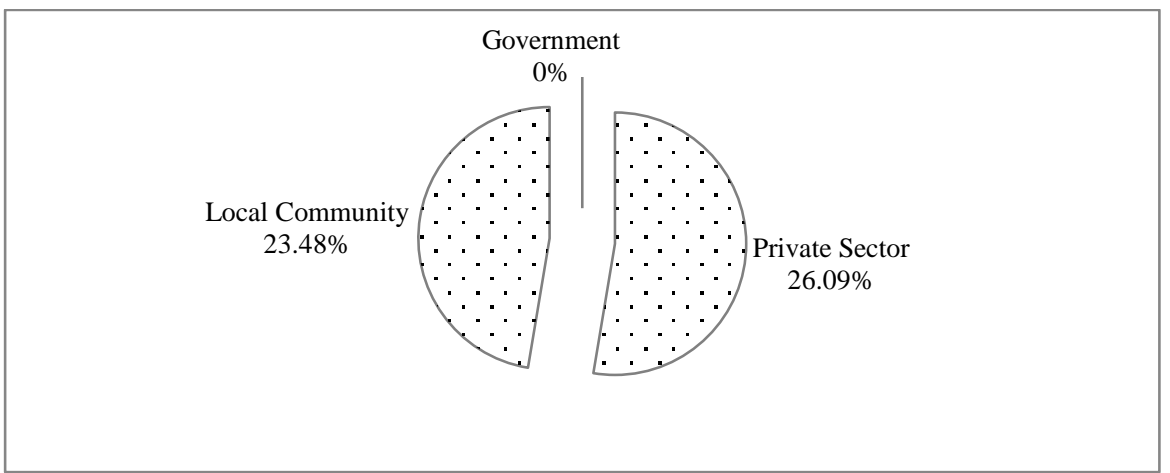

Figure 2(b). Summary of "No" responses to the willingness to pay question ( $\mathrm{n}=57$ )

The respondents gave slightly different reasons for what motivated or encouraged them to pay more. A summary of the various motivations to pay for the conservation of forest resources and biodiversity are presented in Figure 3. A concern over the depletion of the forest and the related sustainable ecology seems to be the most common motivation.

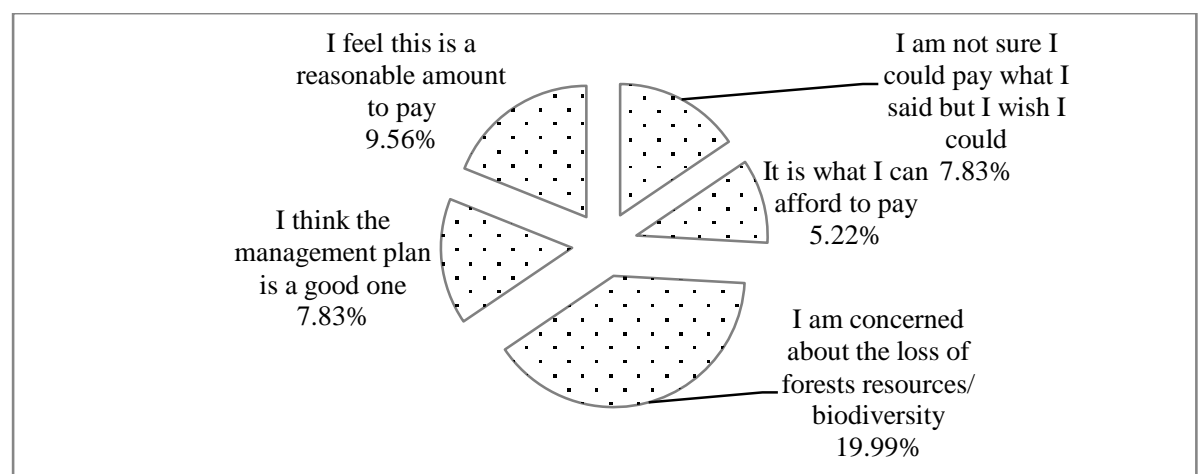

Figure 3: Reasons why respondents are willing to pay to protect the forest resources of Lower Kinabatangan $(\mathrm{n}=58)$

In addition, those respondents who refused to pay more or were unwilling to pay at all were asked to state their personal reasons for refusing to contribute to the conservation of the forest resources in Lower Kinabatangan. In this section, the reasons for the reluctance to pay can be placed into seven categories. The results in Figure 5.4 show that the respondents believe that the users, i.e. the tourists who visit the Lower Kinabatangan to view the nature and the wildlife, should be made to pay more for the conservation of the forest resources. Besides that, most of the local residents were of the opinion that it is the responsibility of the government to protect the forest so as to maintain the 
Normah Abdul Latip , Nurwati Badarulzaman, Azizan Marzuki \& Mohd Umzarulazijo Umar

Sustainable Forest Management in Lower Kinabatangan, Sabah: Issues and Current Practices

ecosystem of the Lower Kinabatangan. The motivations or reasons for the unwillingness to pay for the protection of the forest resources and biodiversity of Lower Kinabatangan are classified in Figure 4.

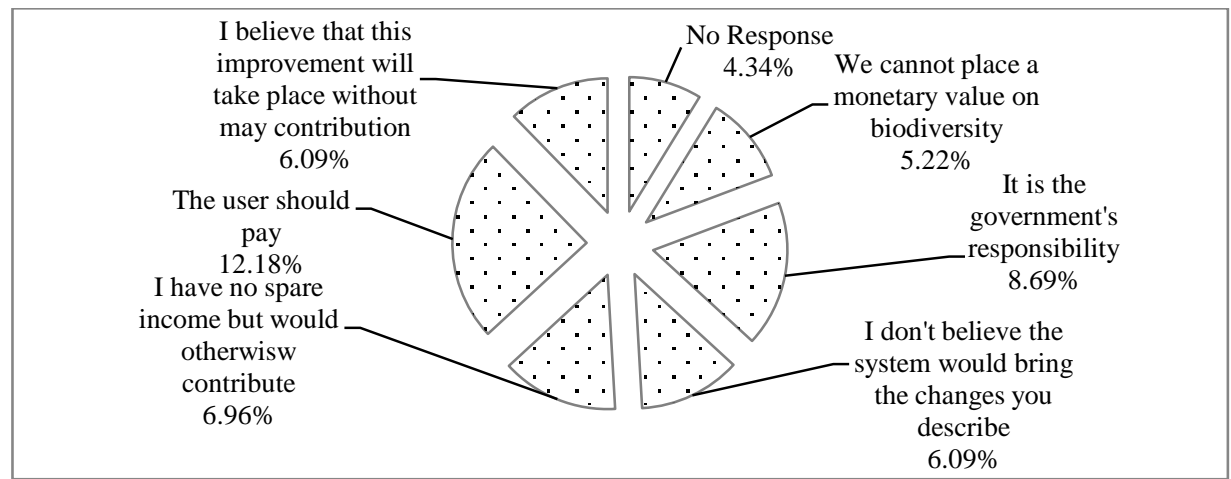

Figure 4: Reasons why respondents are not willing to pay to protect the forest resources of Lower Kinabatangan $(n=57)$

On being asked how much more they were willing to pay, $45.0 \%$ of the respondents said that an acceptable sum would be something between RM2 and RM5, while $41.7 \%$ said they would prefer to pay less than RM2. Nevertheless, $13.2 \%$ of them were prepared to pay more than RM5.

\section{Respondents' Perceptions towards Current Forest Management Practices in Lower Kinabatangan}

The results in this section will answer the second objective of this study. There are various views or perceptions as to whether the management of forest resources in Lower Kinabatangan satisfies the requirements for sustainability. In this regard, instead of being managed, the forest resources in Lower Kinabatangan have been exploited, and this on-going exploitation has become a major obstacle to the achievement of sustainable forest management. In order to explore the perception of respondents towards the sustainability or nonsustainability of the forest management practices in Lower Kinabatangan a series of questions with categorical and scale responses were provided. The results in Figure 5.5 indicate that $53 \%$ of the respondents, comprised of the Government (21.72\%), the Private Sector (14.77\%) and the Local Community $(16.51 \%)$, were of the opinion that the current forest management practices were not sustainable. Nevertheless, $30 \%$ of them believed that forest management was sustainable while the remaining 17\% thought that although the management of the forest was currently unsustainable, yet it could be improved if the right approach was used. 


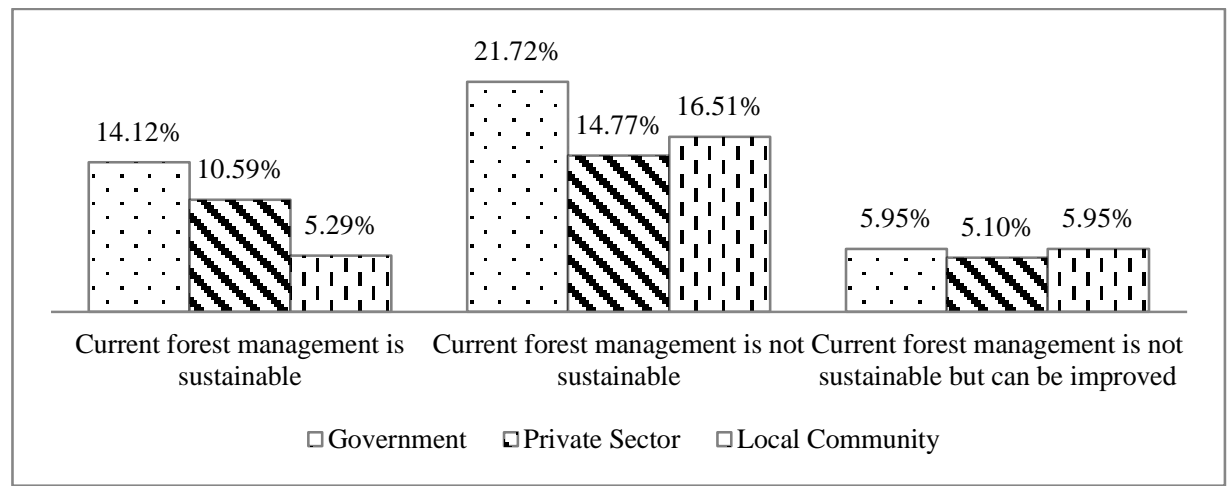

Figure 5: Response towards current forest management practices in Lower Kinabatangan

\section{Respondents' Perceptions towards Efficiency and Success of Legislation and Forest Management in Lower Kinabatangan}

This section presents the results concerning the respondents' views with regard to the efficiency of legislation and forest management in the Lower Kinabatangan area. To assess the perceptions of respondents to these matters, they were requested to indicate their level of agreement or disagreement on the success or efficiency of three key areas where success or failure has a profound impact on the forest management system in Lower Kinabatangan. The results in Figure 6 and Table 2(a) and Table 2(b) indicate that the respondents disagreed that current forest management and planning and also forest protection and strategies have been effective in sustaining forest management in Lower Kinabatangan. However, they agreed that forest legislations and policies can enhance forest sustainability in the study area.

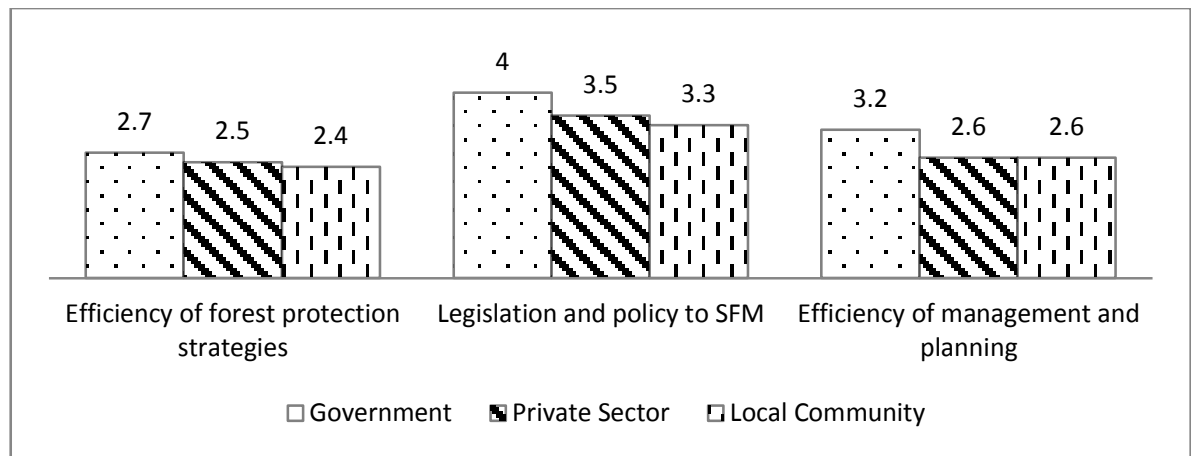

Figure 6: Response towards efficiency and success of legislation and forest management for sustainable forest management in Lower Kinabatangan $(n=115)$ 
Normah Abdul Latip , Nurwati Badarulzaman, Azizan Marzuki \& Mohd Umzarulazijo Umar

Sustainable Forest Management in Lower Kinabatangan, Sabah: Issues and Current Practices

An ANOVA test was also carried out to analyse whether there were any significant differences between the mean responses from all the respondents in the three groups. As shown in Table 2, the efficiency of current forest protection strategies in Lower Kinabatangan are not significant ( $\mathrm{p}$-value of 0.111 ) but the efficiency of forest management and planning (p-values of 0.000 ) and legislations and policies (p-values 0.001 ) for forest sustainability in Lower Kinabatangan are significant at $\alpha=0.05$.

Table 2: Response towards efficiency and success of legislation and forest management for sustainable forest management in Lower Kinabatangan $(n=115)$

\begin{tabular}{|c|c|c|c|c|c|c|}
\hline \multicolumn{7}{|c|}{ Mean response for each group } \\
\hline $\begin{array}{l}\text { Response on } \\
\text { efficiency of } \\
\text { forest } \\
\text { legislation and } \\
\text { management }\end{array}$ & $\begin{array}{l}\text { Governme } \\
\text { nt }(\mathrm{n}=48)\end{array}$ & $\begin{array}{l}\begin{array}{l}\text { Private } \\
\text { sector } \\
(\mathrm{n} \\
35)\end{array}=\end{array}$ & $\begin{array}{l}\text { Local } \\
\text { community } \\
(\mathrm{n}=32)\end{array}$ & $\begin{array}{l}\begin{array}{l}\text { Grand } \\
\text { mean } \\
(\mathrm{n} \\
115)\end{array}= \\
=\end{array}$ & $\begin{array}{l}\mathrm{F} \\
\text { value }\end{array}$ & $\begin{array}{l}\mathrm{p} \\
\text { value }\end{array}$ \\
\hline $\begin{array}{l}\text { Efficiency of } \\
\text { forest } \\
\text { management } \\
\text { and planning }\end{array}$ & 3.2 & 2.6 & 2.6 & 2.8 & 6.2 & $\begin{array}{l}.001 * * \\
*\end{array}$ \\
\hline $\begin{array}{l}\text { Efficiency of } \\
\text { forest } \\
\text { protection } \\
\text { strategies }\end{array}$ & 2.7 & 2.5 & 2.4 & 2.5 & 2.1 & .111 \\
\hline $\begin{array}{l}\text { Legislation } \\
\text { and policy to } \\
\text { SFM }\end{array}$ & 4.0 & 3.5 & 3.3 & 3.6 & 11.2 & $\begin{array}{l}.000 * * \\
*\end{array}$ \\
\hline
\end{tabular}

\section{Respondents' Perceptions towards Factors Constraining the Progress of Forest Management in Lower Kinabatangan}

These sections show the results concerning the perceptions of the respondents with regard to the constraints or obstacles to forest management in Lower Kinabatangan. In this context, to investigate what factors generally obstruct advancements toward forest management in Lower Kinabatangan all the respondents were asked to indicate their level of agreement or disagreement to a series of questions. Figure 7 indicates that the respondents agreed that all the issues concerning forest management, except the unsustainable use of forest resources (biodiversity), are factors that are blocking the attainment of sustainable forest management in Lower Kinabatangan. In addition, the results also indicate that all the respondents agreed that inefficient forest management, conversion of forests to other land uses and illegal land use activities were the 
major blocks to sustainable forest management in Lower Kinabatangan and these issues should be given top priority.

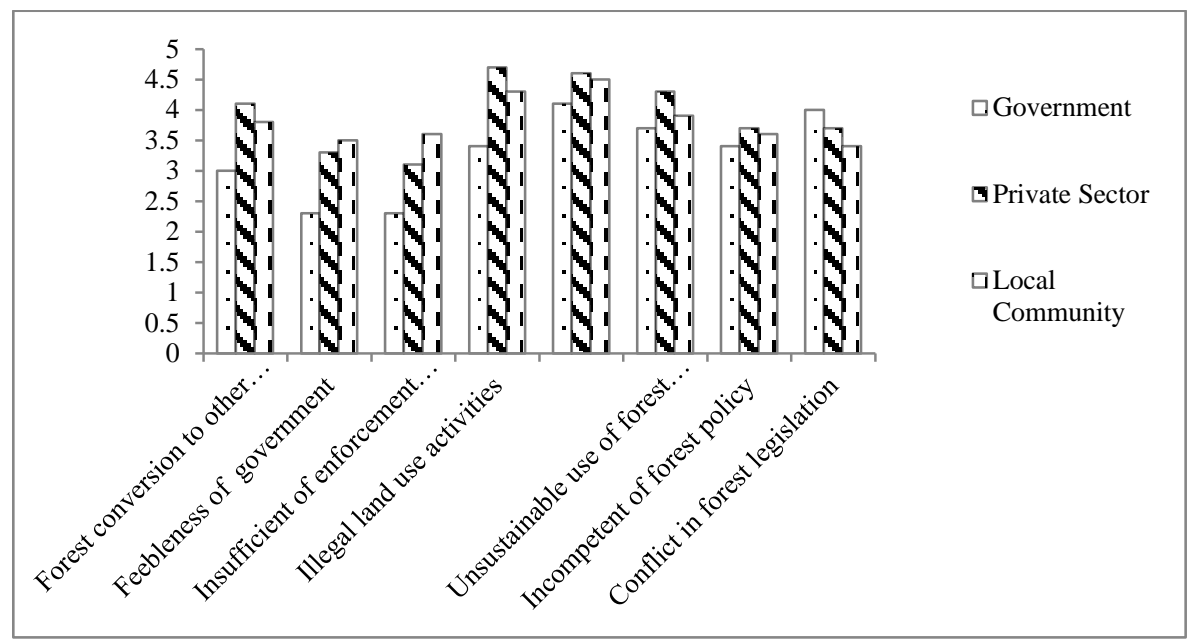

Figure 7: Response to factors constraining the forest sustainability process in Lower Kinabatangan $(n=115)$

Furthermore, an ANOVA test was carried out to determine whether there are any significant differences between the responses from the respondents in the three groups. As can be seen in Table 3, most of the factors were significant at $\alpha=0.05$, with the exception of the unsustainable use of forest resources (biodiversity) in Lower Kinabatangan.

Table 3: Response to factors constraining the forest management process in Lower Kinabatangan $(n=115)$

\begin{tabular}{|l|l|l|l|l|l|l|}
\hline \multicolumn{2}{|l|}{ Mean response for each group } \\
\hline $\begin{array}{l}\text { Response to } \\
\text { constraints } \\
\text { on forest } \\
\text { management }\end{array}$ & $\begin{array}{l}\text { Governm } \\
\text { ent }(\mathrm{n}= \\
48)\end{array}$ & $\begin{array}{l}\text { Private } \\
\text { sector and } \\
\text { NGOs } \\
(\mathrm{n}=35)\end{array}$ & $\begin{array}{l}\text { Local } \\
\text { community } \\
(\mathrm{n}=32)\end{array}$ & $\begin{array}{l}\text { Grand } \\
\text { mean } \\
(\mathrm{n}=115)\end{array}$ & $\begin{array}{l}\text { F value } \\
\text { van }\end{array}$ & $\begin{array}{l}\mathrm{p} \\
\text { value }\end{array}$ \\
\hline $\begin{array}{l}\text { Forest } \\
\text { conversion } \\
\text { to other } \\
\text { land uses }\end{array}$ & 3.0 & 4.1 & 3.8 & 3.6 & 8.9 & $\begin{array}{l}.001^{*} \\
* *\end{array}$ \\
\hline $\begin{array}{l}\text { Feebleness } \\
\text { of } \\
\text { government }\end{array}$ & 2.3 & 3.3 & 3.5 & 3.0 & 15.9 & $\begin{array}{l}.000^{*} \\
* *\end{array}$ \\
\hline
\end{tabular}


Normah Abdul Latip , Nurwati Badarulzaman, Azizan Marzuki \& Mohd Umzarulazijo Umar Sustainable Forest Management in Lower Kinabatangan, Sabah: Issues and Current Practices

\begin{tabular}{|l|l|l|l|l|l|l|}
\hline $\begin{array}{l}\text { Insufficient } \\
\text { enforcement } \\
\text { of laws }\end{array}$ & 2.3 & 3.1 & 3.6 & 3.0 & 14.2 & $.001^{*}$ \\
$* *$ \\
\hline $\begin{array}{l}\text { Illegal land } \\
\text { use activities }\end{array}$ & 3.5 & 4.7 & 4.3 & 4.2 & 11.2 & $.001^{*}$ \\
$* *$ \\
\hline $\begin{array}{l}\text { Incompetent } \\
\text { forest } \\
\text { management }\end{array}$ & 4.1 & 4.6 & 4.5 & 4.4 & 3.1 & $.044^{*}$ \\
\hline $\begin{array}{l}\text { Unsustainabl } \\
\text { e use of } \\
\text { forest } \\
\text { resources }\end{array}$ & 3.7 & 4.3 & 3.9 & 3.9 & 1.9 & .112 \\
\hline $\begin{array}{l}\text { Incompetent } \\
\text { forest policy }\end{array}$ & 3.4 & 3.7 & 3.6 & 3.6 & 1.4 & .271 \\
\hline $\begin{array}{l}\text { Conflict in } \\
\text { forest } \\
\text { legislation }\end{array}$ & 4.0 & 3.7 & 3.4 & 3.7 & 11.2 & $.000^{*}$ \\
\hline
\end{tabular}

5-Point Scale ( $1=$ strongly disagree; 3 = neither disagree nor agree; $5=$ strongly agree $)$

\section{Respondents' Perceptions towards Sectors of Lower Kinabatangan Forestry That Require Reform}

Sustainable forest management can be attained if all the sectors in the Lower Kinabatangan forestry contribute fully to the process of forest management. However, reforms must be instituted in some sectors that have been inefficient and ineffective so as to enhance the sustainability of the forest management. In order to determine which aspects of forestry in Lower Kinabatangan should be reformed so as to ensure that the sector makes the maximum contribution to sustainable forest management, the respondents were asked to indicate their level of agreement or disagreement for reforms in six areas of the forestry sector. The results in Figure 8 show that the respondents agreed that all areas in the forestry sector needed reforms but that among all these, reforms for better legislation, enforcement of laws and policies and forest management and planning strategies were the most important. 
PLANNING MALAYSIA:

Journal of the Malaysia Institute of Planners (2013)

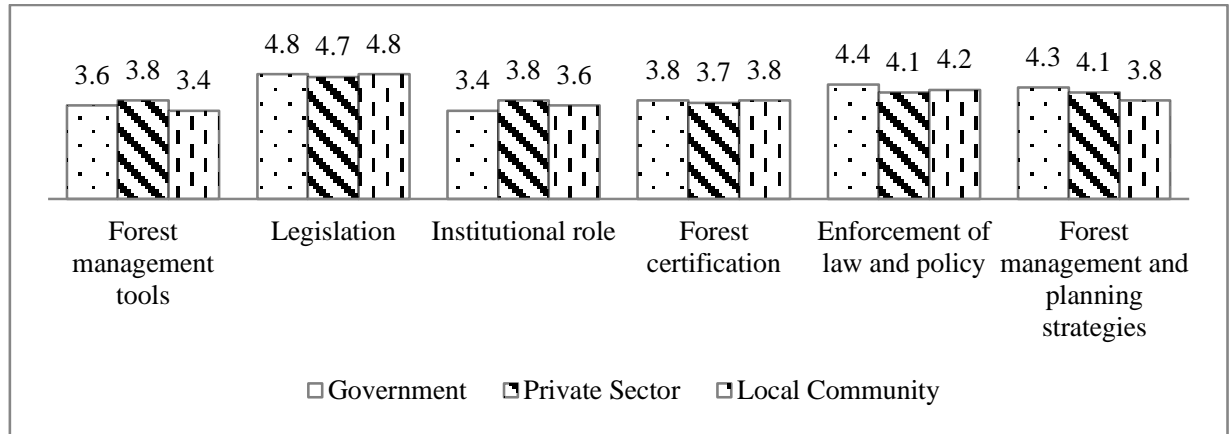

Figure 8: Response on sectors in Lower Kinabatangan forestry requiring reforms $(n=115)$

An ANOVA test was carried out to identify the differences in the mean responses from the respondents in the three groups. The results in Table 4 indicate that only institutional role reforms (p-value 0.041) and forest management and planning strategy reforms ( $\mathrm{p}$-value 0.018 ) were significant at $\alpha=0.05$.

Table 4: Response on reforms required in the forest sector for achieving sustainable forest management in Lower Kinabatangan $(n=115)$

\begin{tabular}{|c|c|c|c|c|c|c|}
\hline \multicolumn{7}{|c|}{ Mean response for each group } \\
\hline $\begin{array}{l}\text { Response to } \\
\text { reforms in } \\
\text { forest sector }\end{array}$ & $\begin{array}{l}\text { Governm } \\
\text { ent }(n= \\
48)\end{array}$ & $\begin{array}{l}\text { Private } \\
\text { sector } \\
\text { and } \\
\text { NGOs } \\
(\mathrm{n}=35)\end{array}$ & $\begin{array}{l}\text { Local } \\
\text { communi } \\
\text { ty } \\
(\mathrm{n}=32)\end{array}$ & $\begin{array}{l}\text { Grand } \\
\text { mean } \\
(\mathrm{n}=115)\end{array}$ & $\begin{array}{l}\mathrm{F} \\
\text { value }\end{array}$ & $\begin{array}{l}\mathrm{p}- \\
\text { value }\end{array}$ \\
\hline $\begin{array}{l}\text { Forest } \\
\text { management } \\
\text { tools }\end{array}$ & 3.6 & 3.8 & 3.4 & 3.6 & 2.9 & .067 \\
\hline Legislation & 4.8 & 4.7 & 4.8 & 4.8 & .55 & .588 \\
\hline $\begin{array}{l}\text { Institutional } \\
\text { role }\end{array}$ & 3.4 & 3.8 & 3.6 & 3.6 & 3.3 & $.041^{*}$ \\
\hline $\begin{array}{l}\text { Forest } \\
\text { certification }\end{array}$ & 3.8 & 3.7 & 3.8 & 3.8 & .04 & .983 \\
\hline $\begin{array}{l}\text { Enforcement } \\
\text { of law and } \\
\text { policy }\end{array}$ & 4.4 & 4.1 & 4.2 & 4.2 & 7.0 & .490 \\
\hline $\begin{array}{l}\text { Forest } \\
\text { management } \\
\text { and planning } \\
\text { strategies }\end{array}$ & 4.3 & 4.1 & 3.8 & 4.1 & 4.2 & $.018 *$ \\
\hline
\end{tabular}


Normah Abdul Latip , Nurwati Badarulzaman, Azizan Marzuki \& Mohd Umzarulazijo Umar

Sustainable Forest Management in Lower Kinabatangan, Sabah: Issues and Current Practices

On the whole, the results from the analysis conducted in this study showed that all the major stakeholders have similar views and are also fully in favour of any action to tackle environmental issues in the Lower Kinabatangan. They also argued that the Lower Kinabatangan has a weak forest management system in terms of policy and law. However, with the cooperation of all concerned the capacity for achieving sustainable forest management can be strengthened.

\section{Forest Management in Sabah}

Sabah's rich forest resources are among the most biologically diverse in the world (Koh \& Wilcove, 2008). Unfortunately, over the last two decades the focus on the economic development of the state has resulted in considerable and severe changes to the landscape. As the state progressed, forest land that was once easily accessible was harvested and stripped for agriculture. According to Hoh and Ishak (2001), Sabah is now covered with oil palm plantations, as palm oil has become the main export, contributing significantly to the income of the state. With the depletion of valuable hardwoods, logging activities also decreased, but the further stripping of the forest lands did not stop there. There was a feverish race to establish oil palm plantations, particularly in the late Eighties and early Nineties (Fletcher, 1997). In this context, many of the private plantation owners were from Peninsula Malaysia, who came over to Sabah in search of cheaper and more abundant lands. The damaged forests were degazetted and replaced by oil palm plantations at an extremely high rate of conversion. Among the states in Malaysia, Sabah has the largest acreage of palm oil plantations and is a major contributor to the economic development of the country (Hoh and Ishak, 2001). The total acreage under oil palm in Sabah has risen to 1.4 million hectares and 3 million tons of crude palm oil came from the state in 2010 (see Figure 1). The palm oil industry is a major component of the state's economy, and is an influential player in the international edible oils market. At present, palm oil is contributing the most to the economy of the state. 


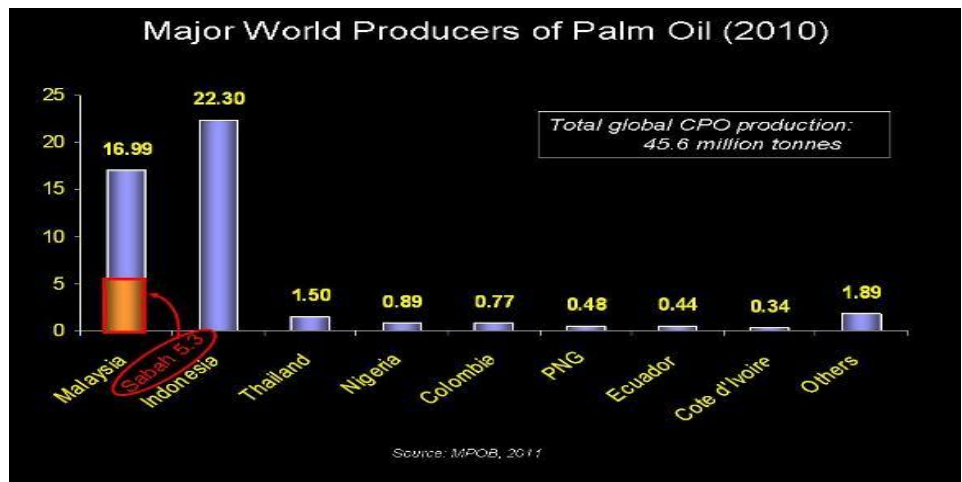

Figure 9: Major World Producers of Palm Oil (2010)

Sources: $M P O B,(2011)$

Under such circumstances, it is no wonder that policy makers and members of the public are expressing their concern that biofuel policies in Malaysia may result in the conversion of rainforests to palm oil plantations in Sabah. Such a consequence would erode the environmental reputation of biofuels as well as damage the ecology, with far-reaching consequences on the economy and the society. Although in recent years there has been a great focus on the impact of replacing forests with oil palm, the increasing role being played by biofuel production in deforestation is being given less attention (Gallagher et al., 2008). According to Gallagher et al. (1989), a recent report commissioned by the United Kingdom government revealed that the conversion of existing agricultural land due to the demand for biofuels is causing rapid changes to land use and, if this situation persists, the biodiversity will be depleted and GHG emissions may even increase instead of decrease. From 1990 to 2005 , more than $50 \%$ of the expansion of oil palm plantations in Sabah happened at the expense of the forests (Koh \& Wilcove, 2008).

However, several changes took place in 1997. It was apparent from the continued destruction of Sabah's forests that the 1984 amendments to the Forest Enactment were inadequate at protecting the forest resources and improving forest management. The policy of the state was changed and short-term licenses were replaced with long-term licences, such as the Sustainable Forest Management License Agreement (SFMLAs), so as to encourage better forest management (Sabah Forestry Department, 1998). The aim is to conserve whatever remains of the forest lands and to sustainably manage them in order to ensure improvements in timber productivity in the long run and protection of the environment. The conditions stipulated for the issuing of the licences are based on the model Deramakot Forest Reserve project, which is being managed by the SFD within the FMU and has been certified by the Forest Stewardship 
Normah Abdul Latip , Nurwati Badarulzaman, Azizan Marzuki \& Mohd Umzarulazijo Umar

Sustainable Forest Management in Lower Kinabatangan, Sabah: Issues and Current Practices

Council (FSC) as having met their principles and criteria for a well-managed forest reserve (Sabah Forestry Department, 2007a). According to Mannan and Yahya (1997), many factors are to be blamed for the "massive depletion of forests" in Sabah, such as harvesting beyond the ability of the forest to regenerate; not giving forests enough time to recover from logging activities through early "re-entry" or "re-logging"; damage to residual stands because of poor logging practices; neglect of silviculture and forest rehabilitation; monetary gain prevailing over environmental restrictions; political changes and instability, and the inability of the forestry profession to put pressure on powerful groups.

During the period from 1975 to 1995 the primary forest cover area shrank from approximately 2.8 million hectares to roughly 300000 hectares (Mannan \& Yahya, 1997) while the area of disturbed forests almost doubled. A study by Mannan and Yahya (1997) showed that the primary forests under the Class II Production Forest category underwent the most severe loss of cover from $98 \%$ in 1970 to just 15\% in 1996. Meanwhile, the Forest Enactment, 1968 was revised for the first time in 1984, marking a significant change in forest laws. This revision involved the division of forest reserves into seven classes, the re-gazetting of the remaining forest reserves so as to include the new classes of forests, and the gazetting of new reserves. For instance, the Deramakot Forest Reserve became the Deramakot Forest Reserve and this showed that forest reserves, particularly those in the Class II Commercial Forest category, could no longer be reclassified within the Sabah Forest Department without the approval of the State Cabinet and the Governor of Sabah (Sabah Forestry Department, 2007a).

On the whole, these problems have brought to the surface the weaknesses that existed in the previous concepts, planning and implementation of forest management in Sabah, such as inadequate cooperation and coordination among the various government extension agencies; lack of prioritization, commitment and support for forest management projects from stakeholders; absence of community participation, meaning that the various communities were left out of the planning and decision making process for forest management, and were not given enough information regarding the aims and objectives of forest management; poor communication due to cultural differences between extension personnel and communities; disunity and internal problems within resettled villages, for example, land and border conflicts and complete reliance on financial aid from the government (Mannan \& Yahya, 1997). 
PLANNING MALAYSIA:

Journal of the Malaysia Institute of Planners (2013)

\section{Issues and challenges of forestry management in Lower Kinabatangan}

The Lower Kinabatangan is made up of various types of forests such as freshwater swamp forests, secondary dry land forest, limestone outcrops and lakes (WWF Malaysia, 2004). A century ago the Lower Kinabatangan was practically covered by forests but today these forests have had to make way for agriculture and the few remaining forests have been badly damaged by selective land use, particularly for agriculture. According to a WWF (2005) report, presently the existing forests in Lower Kinabatangan are fragmented and certain areas are completely inaccessible. Even though commercial logging activities are no longer being carried out in the area, the Lower Kinabatangan forests are not being left alone. According to Pang (2003), due to the shortage of timber for sawmills, the lure of illegal logging activities is strong. Furthermore, the lowland alluvial swamps are perfect for the cultivation of oil palm if they are drained (Azmi, 1996). As such, there are still many applications coming from companies for the conversion of forested land (Pang, 2003). Locals, attracted by the financial rewards, are prepared to give up their private forest land to agriculture. Palm oil companies, bent on expanding the plantations, are offering to buy or lease the land from the local villagers. However, the local villagers are of the opinion that it is more profitable to give up their land to oil palm smallholdings. The repercussions from possible changes to private land use on the wildlife and biodiversity in the area are terrible as the forest land will be even more fragmented. At present, $85 \%$ of the Kinabatangan forest floodplain has been converted to agriculture (Pang, 2003). In 1995, roughly 190,625 hectares of land were used for the cultivation of oil palm in the Kinabatangan district, and this acreage had increased to 303,941 hectares by 2005 (Sabah Institute for Development Studies, 2008). Currently, the land in the Kinabatangan area is being used predominantly for oil palm cultivation and this has presented major problems for forest management here. In Figure 2 below it can be seen that the KWS is fragmented and stands in the midst of private land, most of which has been cultivated with oil palm (Prudente \& Balamurugan, 1999).

In this context, the rich biodiversity and high conservation value of the Lower Kinabatangan area are being increasingly threatened by progressive fragmentation of the forest caused by the development of new palm oil plantations (Prudente \& Balamurugan, 1999). Presently, 75 square kilometres of flood-prone land along the banks of the Kinabatangan River are being cultivated with oil palm (Pang, 2003). Many people consider this land to be unsuitable for oil palm plantations as the land is prone to annual floods. The land owners have responded to this issue in various ways. For instance, some owners have 
Normah Abdul Latip , Nurwati Badarulzaman, Azizan Marzuki \& Mohd Umzarulazijo Umar

Sustainable Forest Management in Lower Kinabatangan, Sabah: Issues and Current Practices

reserved this land for reforestation, while others have preferred to find ways to control the floods every year (WWF, 2005).
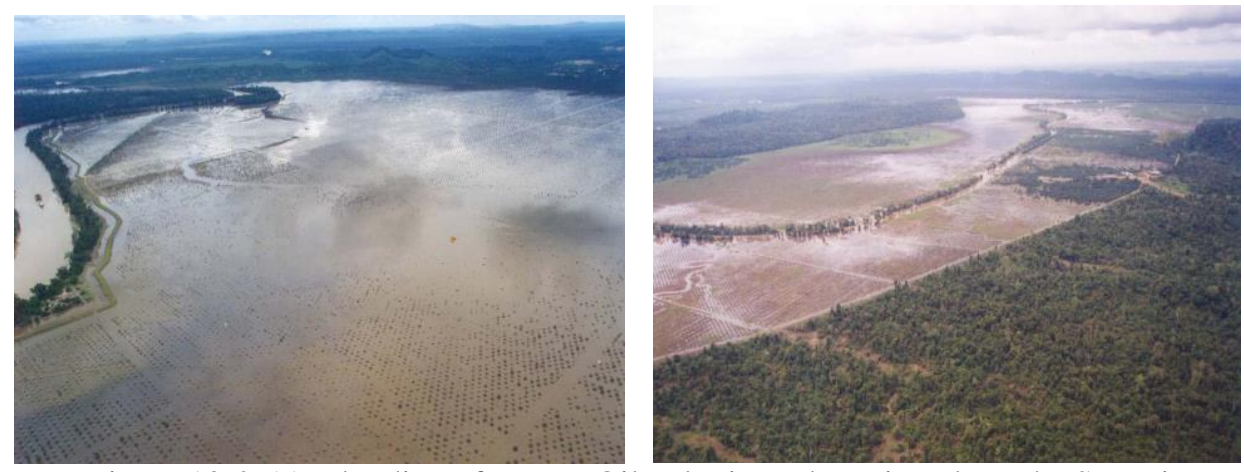

Figure 10 \& 11: Flooding of Young Oil Palm in a Plantation along the Sungai Kinabatangan

Source: Sabah Forestry Department

According to the Department of Irrigation and Drainage, Sabah, Malaysia (1998), although Clause 40 of the Sabah Water Resources Enactment 1998 clearly specifies that land owners must set up a riparian reserve "within 20 metres of the top of the bank of every river, including its estuary, where the river channel is not less than three metres in width" (Department of Irrigation and Drainage Sabah Malaysia, 1998, p. 171), and the Lower Kinabatangan River is more than three metres wide, yet most of the plantation companies in the Kinabatangan appear to have chosen to disregard this ruling. Some of these companies have cleared the riparian reserve to make way for agriculture, while others have done so to get rid of pests (Sabah Forestry Department, 2007a). However, Clause 40 is still a legally enforceable requirement and the establishment of these riparian reserves will help in the creation of corridors linking the forested areas, and will encourage the migration of wildlife. Poor land management can lead to environmental pollution, and in the case of Lower Kinabatangan, the inefficient management of the oil palm plantations has affected the quality of the river water and the ecosystem. From the 1960s, the quality of the water in the Lower Kinabatangan and its streams was deteriorating due to commercial logging, and this situation became worse in the 1980s when the oil palm plantations and factories commenced operations (Prudente \& Balamurugan, 1999). Oil palm development makes the soil compact and this reduces the capacity of the soil to absorb water. As such, the low-water flow of the river is reduced together with the subsequent capacity of the river to dilute pollution. According to Prudente and Balamurugan (1999), the failure to set up riparian reserves along the Kinabatangan has caused river sedimentation and collapse of the river banks. An estimated six millions tonnes 
of sediment are transported annually by the Kinabatangan River. When less light is able to penetrate the river, the feeding and migration of fish and prawns are affected. Furthermore, a rise in surface erosion and fertiliser run-off can lead to suspended sedimentation and increased nutrients in the river, thus choking the fish to death (Azmi, 1996), particularly in the river offshoots and oxbow lakes.

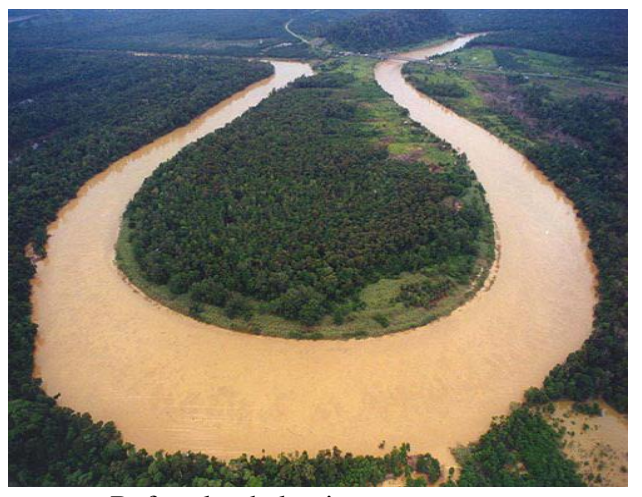

Before land clearing

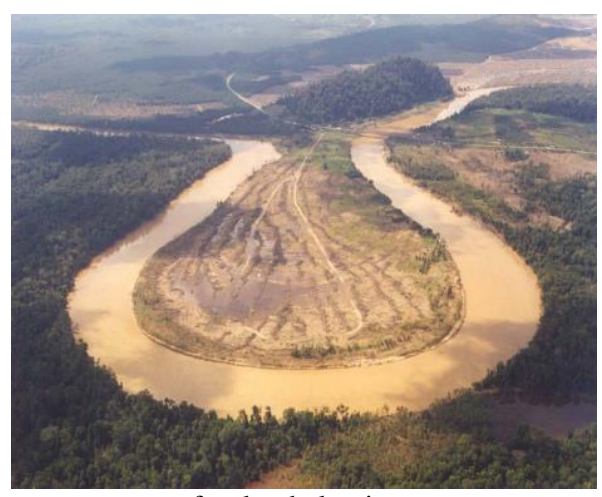

after land clearing

Figure 12 \& 13: Unmonitored and uncontrolled human activities and agriculture development in Lower Kinabatangan (Riparian reserves cleared for oil palm planting)

Sources: Sabah Forestry Department

Another issue is the dispute between the local communities and the foreign immigrants. The increasing employment opportunities in the oil palm industry have probably attracted more and more people to the Kinabatangan district over the past few years. However, most of those employed are foreign immigrants (Payne, 1997), with practically the whole plantation labour force comprising foreign workers such as Indonesians and Filipinos, most of whom are illegals (Azmi, 1996). The pay is low, the work is hard and it looks as though "...only people without the privilege of citizenship are willing to endure the tough work of plantation labour for money which is sufficient only for survival near (Sabah) poverty level" (Payne, 1997, p. 12). This mass entry of migrants into the area has given rise to a number of problems related to the conservation of natural resources, and stretches the natural, infrastructural and social resources to the limit (Azmi, 1996).

Besides that, the absence of cooperation among stakeholders has also created problems in forest management in Lower Kinabatangan (Payne, 1997). In this context, the local communities, relevant government agencies and the private sector should all be involved together in the development and management of forests in the Lower Kinabatangan. However, currently the 
Normah Abdul Latip , Nurwati Badarulzaman, Azizan Marzuki \& Mohd Umzarulazijo Umar

Sustainable Forest Management in Lower Kinabatangan, Sabah: Issues and Current Practices

three sectors are not properly integrated (Prudente \& Balamurugan, 1999). For instance, until today, tourism in the Lower Kinabatangan is heavily dependent on private tour operators who have the necessary capital, skills and the labour force to establish and manage tourism facilities. The operations are run independently, with each tour operator handling their own tourist facilities and operations. However, very few locals are involved as staff or as providers of support services such as fresh food supply, laundry services and local tour guides. For example, since the supply of fresh food is unpredictable in $\mathrm{Kg}$. Sukau, it has to be brought in from Sandakan, even for some of the villagers themselves (Prudente \& Balamurugan, 1999). Therefore, if the locals want to be part of the sustainable development of the area, they must be engaged and see not just the economic benefits but also the preservation of their culture and lifestyle. Success will come when there is an understanding of how conservation, social development and economic development are inter-related, and these issues are addressed correctly (Azmi, 1996).

In conclusion, the question arises as to why the problems observed in the Kinabatangan area in terms of land use and forestry status have given rise to unsustainability and why they have been allowed to continue unchecked. Several main factors have been identified from this study. Firstly, the history behind the introduction of the palm oil industry in Kinabatangan. During the mid-Seventies to early Eighties, when most forest reserves were de-reserved for timber production and the land was available for fragmentation, it was implicitly assumed that a total conversion of land use and economy from logging on State-owned land to large scale private agriculture would be to the advantage of all stakeholders (Sabah Forest Department, 2006). Not enough thought was given as to how the revenue earned would be allocated and invested, or to the costs involved and the availability of workers for the large plantations, or to the protection of the natural environment, particularly water and biodiversity. Secondly, there is no comprehensive land use plan to officially manage the allocation of land in Kinabatangan. The preparation of such a plan would involve the examination of such issues and ensure that land is allocated based on actual conditions and requirements, including environmental, social and economic considerations (Prudente \& Balamurugan, 1999). In addition, there is no confidence and commitment among stakeholders with regard to plans for sustainable forest management in Lower Kinabatangan because in the top-down approach or expert-based approach, for example, the experts make the plans without consulting the stakeholders, who are only informed at the start or end of the planning process (Payne, 1989). On the whole, forest practices in Lower Kinabatangan have not succeeded in improving the environmental conditions in the forests due to a lack of involvement by all stakeholders, especially the locals. In this case, the lack of participation by the local 
community indicates that the locals were not included from the start in the planning and decision-making concerning forest management, and they were not well-informed about the aims and objectives of the forest management process (Payne, 1989). Furthermore, the locals, who are used to having ample timber and land available and earning a living from these resources, are not given enough opportunities to change to other economic activities. In such circumstances, an analysis of the forest management process in Lower Kinabatangan reveals an imbalance between the economic, social and ecological aspects.

\section{CONCLUSION}

In conclusion, there is still cause for concern over forest management in Malaysia, and especially in Sabah, compared to any other developing country in the world (Mannan \& Yahya, 1997). Previous studies have shown that over the years there has been a great increase in deforestation. In fact, these weaknesses are mainly with regard to forest management policies and legal aspects, the planning and control of forests, and the cooperation between the sectors involved. In addition, unsustainable land use development, for instance the cultivation of oil palm, which requires large areas of land, have resulted in several parts of the interior having to face the threat of forest extinction and the impact of increased deforestation, such as in the Lower Kinabatangan, Sabah. The result of the empirical analysis conducted in this study confirmed the theoretical setting with regard to the involvement of the participating forest management and planning stakeholders in a forest sustainability plan. In this context, all stakeholders (Government (G), Private Sector and NGOs (PS) and the Local Community (LC)) should be involved in the sustainable forest management process. They have to be equitably integrated at each step of the forest planning process, in the implementation of the outcome, and especially in the sharing of the benefits obtained from the resources and which are necessary for building or proposing a new forest management so as to successfully attain sustainable forest management in Lower Kinabatangan. 
Normah Abdul Latip , Nurwati Badarulzaman, Azizan Marzuki \& Mohd Umzarulazijo Umar

Sustainable Forest Management in Lower Kinabatangan, Sabah: Issues and Current Practices

\section{REFERENCES}

Azmi, R. (1996). Protected ares and rural communities in Lower Kinabatangan region of Sabah: Natural resources use by local communities and its implications for managing protected areas. Sabah Society Journal, 13, 1-32.

Cissel, J. S., Swanson, F.J., McKee, W.A., \& Burditt, A.L. (1994). Using the past to plan the future in the Pacific Northwest. Journal of Forestry, 92 30-31.

Food and Agriculture Organization (FAO), (2001). Global Forest Assessment. New York: FAO Forestry Paper no. 140, Main report.

Fletcher, P. (1997). The Lower Kinabatangan: The Importance of Community Consultations in Ecotourism Development. Ecotourism for foreat conservation and community development: Proceedings of an International Seminar, 28-31 January 1997, (pp. 213219). Bangkok, Thailand.

Gallagher, T., \& Patrick-Riley, K. (1989). The Readability of Federal Land Management Plans. Environmental Management, 13 (1): 85-90.

Halimaton Saadiah Hashim, Sarah Aziz and Rahimah A. Aziz. (2011). Conservation with development: Showcasing Langkawi Geopark. Journal of the Malaysian Institute of Planners, 9, 1-24.

Hoh, \& Ishak. (2001). Oil palm Cultivation in the Lower Kinabatangan Floodplains: A Case Study. Making land Use Sustainable in the Lower Kinabatangan Floodplains Forum. Kota Kinabalu, Sabah.

Kinabatangan District Office. (2007, August 1). Agriculture in Kinabatangan. (Abdul Latip, N., Interviewer)

Koh, L.P. \& Wilcove, D. S. (2008). Cashing in Palm Oil for Conservation. Nature 448,

993-994.

Kohm, K.A \& Franklin J.F. (1997). Creating a forestry for the 21st century: The science of ecosystem management. Washington D.C: Island Press.

Mannan, S., \& Yahya, A. (1997). Sustainable Forest Management in Sabah. Proceedings Seminar on Sustainable Forest Management, Vol.27 (pp. 51-74). Kota Kinabalu, sabah: Sabah Forest Department.

Ong Puay Liu and Sharina A. Halim. (2011). Planning for heritage tourism: The case of Langkawi Geopark. Journal of the Malaysian Institute of Planners, 9, 121-144.

Pang, C. (2003). Creating a conservation vision for the Kinabatangan: A corridor of life. Sabah Society Journal, 20, 65-77.

Payne, J. (1997). The Kinabatangan Floodplain: An Introduction. Malaysia: WWF-Malaysia.

Prudente, C. \& Balamurugan, G. (1999). Sungai Kinabatangan "Partner for Wetlands" Project: A Partnership for Sustainable Development and Conservation. Sabah Society Journal, 16, 41-56

Sabah Forest Department. (1997). Annual Report of Sabah Forestry. Sabah, Malaysia: Sabah Forest Department.

Sabah Forest Department. (2007a). Sabah Forest Department. Retrieved from Sabah ForestDepartment: http://www.forest.sabah.gov.my/policies/legislation.asp167

World Bank. (2006). Environmentally and socially sustainable development 3. Africa : Country Department 07, Africa Region. Report No: 33790-CM, 174 p

World Wildlife Fund-Malaysia (WWF), (2005). Kinabatangan Flood Plain Forest Conservation Project Phase II (July 2005-June 2007). Sabah: WWF-Malaysia.

World Wildlife Fund-Malaysia (WWF), (2004). Kinabatangan A Corridor of Life. Brochure for Partners for Wetlands Project. Sabah: WWF-Malaysia.

Yamane, T. (1967). Elementary sampling theory. New Jersey: Englewood Cliffs, Prentice Hall. 